\title{
Histochemical and morphological features of biopsied and stripped oocytes from the Brazilian endangered teleost pirapitinga, Brycon nattereri (Characiformes)
}

\author{
Alexandre N. Maria ${ }^{2,5}$, Laura H. Orfão $0^{2,6}$, Elizete Rizzo ${ }^{3}$,Alexandre Ninhaus-Silveira ${ }^{4}$ \\ and Ana T.M. Viveiros ${ }^{1,2}$ \\ Department of Animal Science, Federal University of Lavras, UFLA, Lavras, MG; Department of Morphology, Institute of \\ Biological Sciences, Federal University of Minas Gerais, UFMG, Belo Horizonte, MG; and Department of Biology and Animal \\ Science, São Paulo State University - FEIS, Ilha Solteira, SP, Brazil
}

Date submitted: 03.05.2013. Date revised: 27.09.2013. Date accepted: 30.10 .2013

\section{Summary}

The aim of the present study was to characterize biopsied and stripped oocytes from the Brazilian endangered teleost pirapitinga (Brycon nattereri) using histochemical and morphological analyses. Biopsied oocytes had a mean diameter of $2.225 \mathrm{~mm}$ (modal diameter: $2.312 \mathrm{~mm}$ ), complete vitellogenesis and a central or slightly eccentric nucleus. Neutral polysaccharides were detected in the follicular cells, zona radiata and yolk globules, while acidic polysaccharides were detected in the follicular cells and cortical alveoli. Ten out of the 19 females treated with two doses of carp pituitary extract (cPE) released oocytes, which were also analysed. Stripping occurred $292 \pm 39$ degree-hours after the second dose of cPE and led to a mean spawning weight of $36.2 \mathrm{~g}, 10 \%$ spawning index, 241 oocytes/g of ova, 8222 oocytes/female and 23 oocytes/g of body weight. Stripped oocytes had a mean diameter of $2.33 \mathrm{~mm}$ and a mode at $2.375 \mathrm{~mm}$, were weakly adhesive and coloration ranged from wine to brown. Under scanning electron microscopy, stripped oocytes exhibited a single funnel-shaped micropyle located at the animal pole and a zona radiata that measured $7.7 \mu \mathrm{m}$ in thickness with eight pore canals $/ \mu \mathrm{m}^{2}$. Oocyte morphology in Brycon nattereri is similar to that found in other species of the genus, except for the larger size and weaker adhesiveness. These findings provide essential information for a better understanding of the reproductive biology of B. nattereri and the establishment of conservation measures for this threatened species.

Keywords: Fish, Oocyte surface, Reproduction, Spawning, Ultrastructure

\section{Introduction}

Freshwater fishes of the genus Brycon (Characiformes) are well distributed in Central and South America and

\footnotetext{
${ }^{1}$ All correspondence to: Ana TM Viveiros. Department of Animal Science (DZO), Federal University of Lavras, UFLA, PO Box 3037, Lavras, MG, 37200-000, Brazil. e-mail: ana.viveiros@dzo.ufla.br; anatmviveiros@hotmail.com

${ }^{2}$ Department of Animal Science (DZO), Federal University of Lavras, UFLA, Lavras, MG, Brazil.

${ }^{3}$ Department of Morphology, Institute of Biological Sciences, Federal University of Minas Gerais, UFMG, Belo Horizonte, MG, Brazil.

${ }^{4}$ Department of Biology and Animal Science, São Paulo State University - FEIS, Ilha Solteira, SP, Brazil.

${ }^{5}$ Present address: Embrapa Coastal Tablelands, Aracaju, SE, Brazil.

${ }^{6}$ Present address: Alfenas University, Alfenas, MG, Brazil.
}

inhabit most Brazilian rivers. This genus comprises about 40 species (Zaniboni-Filho et al., 2006), six of which, including the pirapitinga (Brycon nattereri Günther 1864), are on the national list of fish species that are threatened with extinction (Rosa \& Lima, 2008). Fishes of this genus have a silvery-grey colour and are important to commercial and subsistence fishing (Gomiero \& Braga, 2007). Brycon nattereri is endemic to the upper Paraná, São Francisco and upper Tocantins River basins and its populations are declining due mainly to deforestation, water pollution and river damming (Rosa \& Lima, 2008). Actions such as the maintenance and restoration of natural habitats and research on reproductive biology have been highlighted as the best ways to ensure the conservation of B. nattereri (Lima et al., 2007).

Spring/summer is the predominant spawning season of species of the genus Brycon, except for 
B. petrosus, which reproduces in winter (Kramer, 1978), and $B$. opalinus, which has two reproductive peaks - one in spring/summer and another in autumn (Gomiero \& Braga, 2007). Dependent on the river location, the spawning season for B. nattereri occurs in autumn or winter (dry season; Lima et al., 2007). As with most fish in captivity, the collection of $B$. nattereri gametes for artificial reproduction requires hormone induction (Oliveira et al., 2007; Viveiros et al., 2012).

Studies have been carried out on male reproductive characteristics for B. nattereri (Oliveira et al., 2007; Viveiros et al., 2012), but to our knowledge no similar studies on female reproductive characteristics can be found in the literature. Knowledge on the histological and ultrastructural features of oocytes can help optimize reproduction management and increase the efficiency of artificial reproduction techniques (Isaú et al., 2013). Moreover, carbohydrate histochemistry contributes to the understanding of egg adhesiveness. Thus, the aim of the present study was to characterize biopsied and stripped oocytes from Brycon nattereri using histochemical and morphological analyses.

\section{Materials and methods}

Females were obtained from the Fish Culture Station of the Minas Gerais Power Company (CEMIG) in the city of Itutinga, state of Minas Gerais, Brazil. This experiment was carried out during the spawning season for Brycon nattereri (May to August). The region is characterized by a dry winter with very low rainfall (nearly zero in some years) and temperatures between 14 and $26^{\circ} \mathrm{C}$.

\section{Histochemical and morphological analysis of biopsied oocytes}

All fish were handled following the guidelines for animal experimentation described in Van Zutphen et al. (2001). During the experimental period, all females were examined weekly and those with a swollen abdomen and reddish genital pore were selected $(n=19)$. Ovarian biopsies were performed to determine oocyte diameter and for carbohydrate histochemical evaluation. For these techniques, fish were anesthetized with benzocaine (ethyl aminobenzoate; $60 \mathrm{mg} / \mathrm{l}$ of water) and a sample of approximately 60 biopsied oocytes/female was collected with the aid of a plastic urethral catheter inserted into the urogenital papilla. Half of each sample was fixed in Gilson's solution $(50 \mathrm{ml}$ of $60 \%$ ethanol, $440 \mathrm{ml}$ of distilled water, $7 \mathrm{ml}$ of nitric acid, $10 \mathrm{~g}$ of mercuric chloride and $9 \mathrm{ml}$ of glacial acetic). The diameter of each oocyte was measured under a stereomicroscope with a micrometric ocular, following the method described by
Isaú et al. (2013). The frequency distribution of oocyte diameters was calculated in classes of $100 \mu \mathrm{m}$. The remaining oocytes in the samples were fixed in Bouin solution for $12 \mathrm{~h}$ and subjected to histological and carbohydrate histochemical analyses. For this purpose, oocytes were embedded in paraffin, cut to a thickness of 3-5 $\mu \mathrm{m}$ and stained with periodic acid-Schiff (PAS) stain in order to detect neutral polysaccharides and Alcian blue $(\mathrm{AB})$ at $\mathrm{pH} 2.5$ for the detection of acidic polysaccharides (Pearse, 1985). Reactivity of the oocyte structures (follicular cells, zona radiata, cortical alveoli and yolk globules) to carbohydrate histochemistry was classified as follows: negative reaction $(-)$, positive reaction $(+)$ and strongly positive reaction $(++)$.

\section{Induction of spawning and morphological analysis of stripped oocytes}

All 19 females selected for reproduction were transferred from a pond to an aquarium with a water temperature of $18 \pm 1{ }^{\circ} \mathrm{C}$ and oxygen at $7-8 \mathrm{mg} / 148 \mathrm{~h}$ prior to hormone induction. Each female received two intramuscular injections of carp pituitary extract (cPE; Argent Chemical Laboratory, Redmond, Washington, USA) at 0.4 and $4.0 \mathrm{mg} / \mathrm{kg}$ body weight with a 12-h interval. Between 14 and $18 \mathrm{~h}$ after the second dose, all females were hand-stripped. For the fish that responded to $\mathrm{cPE}$ treatment and released oocytes ( $n=10$ females), the following variables were determined: body weight, standard length, total length, ova weight, spawning index (ova weight $\times 100$ /body weight), number of oocytes/g of ova, number of oocytes/female and number of oocytes/g body weight.

A sample of stripped oocytes was collected and fixed in Gilson's solution for 30 min for the measurement of oocyte diameter, which was determined as described for the biopsied oocytes. Oocytes were assessed for adhesiveness under macroscopic analysis and classified as adhesive (when oocytes stuck firmly to each other and formed a coherent egg mass), weakly adhesive (when oocytes adhered to each other, but became free under slight agitation) and non-adhesive (when oocytes were completely free) (Rizzo et al., 2002). A third sample of stripped oocytes from each female was fixed in modified Karnovsky solution (2.5\% glutaraldehyde, $2.5 \%$ paraformaldehyde in $50 \mathrm{mM}$ sodium cacodylate buffer, $\mathrm{pH} 7.2,1 \mathrm{mM}$ $\mathrm{CaCl}_{2}$ ). The oocytes were post-fixed in $1 \%$ osmium tetroxide for $4 \mathrm{~h}$ at room temperature, washed in 0.1 $\mathrm{M}$ cacodylate buffer ( $\mathrm{pH}$ 7.4), dehydrated through an increasing gradient of acetone solutions (25, 50, 75,90 and $100 \%$ ), dried with $\mathrm{CO}_{2}$ in a PELCO CPD 030 critical-point dryer (Leica Microsystems, Wetzlar, Germany), coated with gold under vacuum conditions with SEM Coating Unit SCD 050 (Leica Microsystems) 


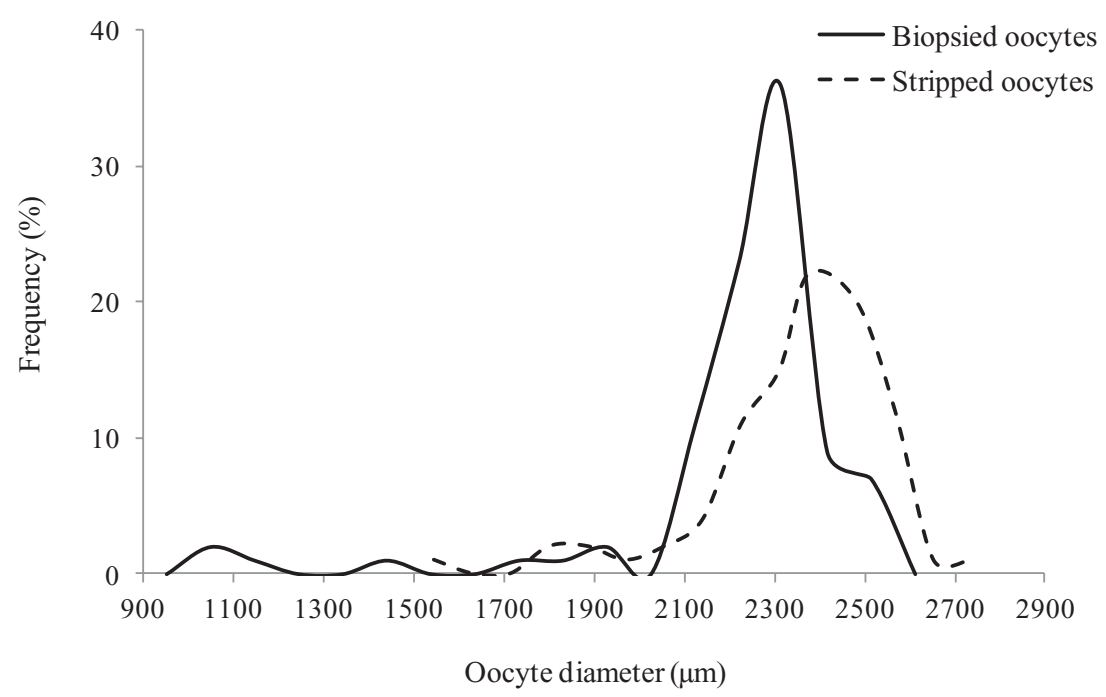

Figure 1 Frequency distribution of biopsied (-) and stripped (---) oocytes diameter of pirapitinga Brycon nattereri after carp pituitary extract treatment.

and examined with a scanning electron microscope (LEO EVO 40 XVP ESC, Carl Zeiss SMT, LEO Electron Microscopy Group, Oberkochen, Germany) equipped with a digital camera, and following the method described by Isaú et al. (2013). Digital images of the oocytes were used for the morphometric analysis of the structures. Micropyle diameter ( $n=18$ oocytes), thickness of the zona radiata ( $n=21$ oocytes) and number of pore canals $/ \mu \mathrm{m}^{2}(n=30$ oocytes) were determined using the LEO-SRV32 software (Microsoft Windows version).

\section{Results}

\section{Histochemical and morphological analysis of biopsied oocytes}

A unimodal frequency distribution was found for the biopsied oocyte diameter among the 19 females used in the present study. Oocyte diameter ranged from $1.000-2.563 \mathrm{~mm}$, with a mean of $2.225 \pm 0.262 \mathrm{~mm}$ and a mode at $2.312 \mathrm{~mm}$ (Fig. 1).

In the histological analysis, most biopsied oocytes had complete vitellogenesis, yolk globules occupied most of the ooplasm, different sizes of cortical alveoli were aligned in layers, there were central or slightly eccentric nucleus with multiple peripheral nucleoli, zona radiata with a thick inner layer and thin outer layer, and a squamous follicular cell layer supported by a basal membrane. Perinucleolar oocytes with finely basophilic cytoplasm, central nucleus and several peripheral nucleoli were also observed in the ovarian sections.

In the carbohydrate histochemical analysis, neutral polysaccharides were detected in the follicular cells, zona radiata and yolk globules (PAS positive) and acidic polysaccharides were detected in the follicular cells and cortical alveoli (AB positive; Table 1).

\section{Induction of spawning and morphological analysis of stripped oocytes}

Ten out of the 19 females that had been treated with cPE subsequently released oocytes. These females had a mean of body weight of $379 \mathrm{~g}$, standard length of $28.7 \mathrm{~cm}$ and total length of $32.1 \mathrm{~cm}$. Stripping occurred $292 \pm 39$ degree-hours after the second dose of cPE and led to a mean spawning weight of $36.2 \mathrm{~g}$, $10 \%$ spawning index, 241 oocytes/g of ova, 8222 oocytes/female and 23 oocytes/g of body weight (Table 2). The diameter of the stripped oocytes ranged from $1.344-2.781 \mathrm{~mm}$, with mean of $2.330 \pm 0.222 \mathrm{~mm}$ and a mode at $2.375 \mathrm{~mm}$ (Fig. 1). The oocytes adhered to each other, but became free under mild agitation and were thus classified as weakly adhesive. Oocyte coloration ranged from wine to brown.

Under scanning electron microscopy, stripped oocytes were devoid of a gelatinous cover, had a single micropyle and exhibited pore canals that were distributed along the surface of the zona radiata. The micropyle was characterized by a conical vestibule and a micropylar canal that crossed the zona radiata (Fig. 2A). An inner layer of folds formed grooves in the micropylar vestibule. The outer opening of the micropylar vestibule had an oblong shape with the largest diameter at $20.4 \mu \mathrm{m}$ and the smallest at $18.7 \mu \mathrm{m}$ (Table 3). The zona radiata was smooth, (Fig. 2B) with pore canals (Fig. 2C) and were devoid of specialized structures such as adhesive filaments. At the vegetative pole, the surface of the zona radiata exhibited a uniform distribution of eight pore 
Table 1 Reactivity of biopsied oocyte structures in carbohydrate histochemical analysis of Brycon nattereri

\begin{tabular}{lcc}
\hline & $\begin{array}{c}\text { Periodic acid-Schiff } \\
\text { (PAS; neutral } \\
\text { polysaccharides) }\end{array}$ & $\begin{array}{c}\text { Alcian blue (AB; } \mathrm{pH} \\
2.5 \text { acidic } \\
\text { polysaccharides) }\end{array}$ \\
\hline Follicular cells & ++ & + \\
Zona radiata & + & - \\
Cortical alveoli & - & + \\
Yolk globules & + & - \\
\hline
\end{tabular}

- , negative reaction; + , positive reaction; ++ , strongly positive reaction.

Table 2 Body length and weight of Brycon nattereri and spawning quality after treatment with carp pituitary extract $(n=10)$

\begin{tabular}{lccc}
\hline Parameter & $\begin{array}{c}\text { Mean } \pm \text { standard } \\
\text { deviation (SD) }\end{array}$ & Min-Max & $\begin{array}{c}\text { Coefficient of } \\
\text { variation (CV) }\end{array}$ \\
\hline Total length $(\mathrm{cm})$ & $32.1 \pm 2.1$ & $27.9-35.6$ & 7 \\
Standard length $(\mathrm{cm})$ & $28.7 \pm 1.8$ & $25.0-31.6$ & 6 \\
Body weight $(\mathrm{g})$ & $379 \pm 79$ & $300-500$ & 21 \\
Ova weight $(\mathrm{g})$ & $36.2 \pm 12.7$ & $16.0-67.8$ & 35 \\
Spawning index $(\%)^{a}$ & $10 \pm 3$ & $6-14$ & 27 \\
Number of oocytes /g of ova & $241 \pm 61$ & $154-354$ & 25 \\
Number of oocytes /female & $822 \pm \pm 2012$ & $5008-12001$ & 24 \\
Number of oocytes /g body weight & $23 \pm 7$ & $13-36$ & 30 \\
\hline
\end{tabular}

${ }^{a}$ Spawning index $=$ ova weight $\times 100 /$ body weight.

canals $/ \mu \mathrm{m}^{2}$ with a greater diameter compared with the animal pole (Fig. 2D). The plasma membrane had long, thin filaments (microvilli) that formed a dense coat (Fig. 2E). The cortical alveoli were aligned in layers that were located in the cortical cytoplasm immediately below the plasma membrane and more internally, with yolk granules that occupied most of the oocyte. The presence of pore canals on the surface of the plasma membrane and impressions left by the cortical alveoli after rupture were also observed (Fig. 2F).

\section{Discussion}

The present study offers a first analysis of female reproductive parameters and oocyte morphology in Brycon nattereri. Relative fecundity was low (23 oocytes/g body weight) and the biopsied oocytes had a large diameter $(2.312 \mathrm{~mm})$. Among females of this genus, B. opalinus had a mean of 31 oocytes $/ g$ body weight and a mean oocyte diameter of 1.90 mm (Narahara et al., 2002; Gomiero \& Braga, 2007), $B$. insignis had a mean of 60 oocytes/g body weight and an oocyte diameter of $1.25 \mathrm{~mm}$ (Andrade-Talmelli et al., 2002) and B. orthotaenia had 105 oocytes/g body weight and an oocyte diameter of $1.479 \mathrm{~mm}$ (Sato et al., 2003). The distribution pattern of the diameter of biopsied oocytes has been successfully used to identify females that were suitable for reproduction, as this variable indicates the degree of ovarian development (West, 1990).

In the present study, unimodal distribution was found in the oocyte diameter of $B$. nattereri from mid autumn to mid winter, when the most oocytes were at the same maturation stage, with complete vitellogenesis and a central or slightly eccentric nucleus, a finding that suggested the presence of a group-synchronous type of oocyte development. In the final stage of oocyte maturation, the germinal vesicle (nucleus) migrates from a central position to the periphery of the oocyte before the resumption of meiosis and breakdown of the germinal vesicle (Grier \& Neidig, 2011).

Vitellogenic oocytes from B. nattereri were coated with a smooth zona radiata with pore canals and neutral polysaccharides. These characteristics constitute a less complex apparatus of egg binding to the substrate and do not ensure a strong degree of adhesiveness (Riehl \& Patzner, 1998). Similarly, other species of Characiformes have non-adhesive (Isaú et al., 2013) or weakly adhesive oocytes (Rizzo et al., 2002; Rizzo \& Godinho, 2003). In contrast, acidic polysaccharides have been commonly detected on the surface of the zona radiata in adhesive oocytes (Rizzo \& Bazzoli, 1991; Riehl \& Patzner, 1998; Gomes et al., 2007; Weber et al., 2012). In the wild, $B$. nattereri females spawn in 

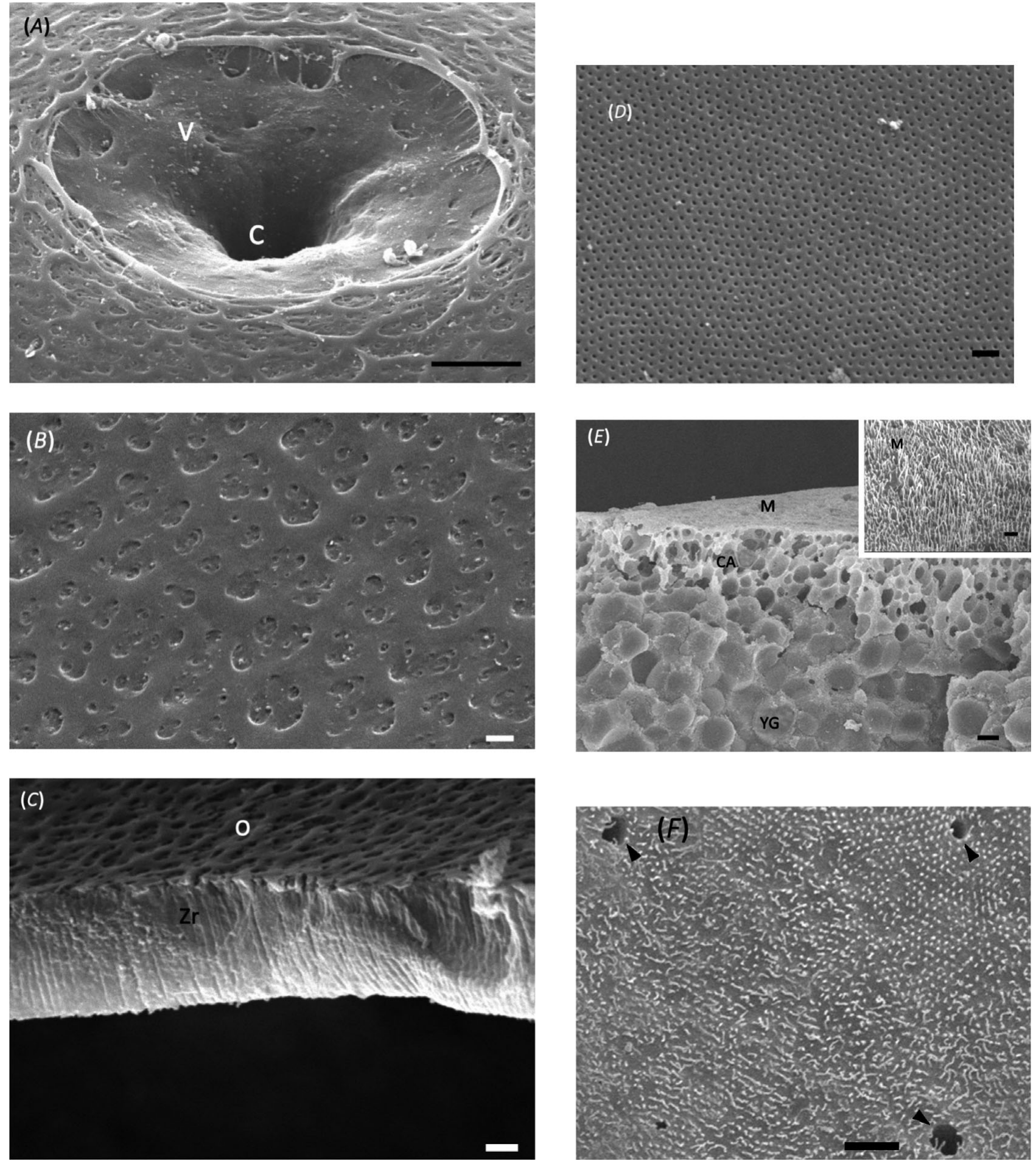

Figure 2 Scanning electron micrographs of stripped oocytes of Brycon nattereri. $(A)$ Details of micropyle with vestibule (v) and micropylar canal (c). (B) External oocyte surface at animal pole. $(C)$ Fractured zona radiata $(\mathrm{Zr})$ with pore canals at the oocyte surface (o). (D) Pore canals in the surface of the zona radiate at the vegetative pole. (E) Cross-section of the oocyte, showing the plasma membrane (M), cortical alveoli (CA) and yolk globules (YG). insertion: microvilli of the plasma membrane. (F) Outer surface of the oocyte plasma membrane showing the pore canals left by the cortical alveoli (arrowheads). Scale bars $=20 \mu \mathrm{m}$ $(A), 2 \mu \mathrm{m}(B-E)$; and $10 \mu \mathrm{m}(F)$. 
Table 3 Morphometry of stripped oocytes from Brycon nattereri

\begin{tabular}{|c|c|c|c|c|c|}
\hline & & No. of oocytes & $\begin{array}{c}\text { Mean } \pm \text { standard } \\
\text { deviation }(\mathrm{SD})\end{array}$ & Min-Max & $\begin{array}{c}\text { Coefficient of } \\
\text { variation }(\mathrm{CV})\end{array}$ \\
\hline \multirow[t]{2}{*}{ Zona radiata } & Thickness $(\mu \mathrm{m})$ & 21 & $7.7 \pm 0.3$ & $7.2-8.4$ & 4 \\
\hline & Number of pore canals $/ \mu \mathrm{m}^{2 a}$ & 30 & $8 \pm 1$ & 7-8 & 12 \\
\hline \multirow[t]{2}{*}{ Micropyle diameter $^{b}$} & Largest $(\mu \mathrm{m})$ & 18 & $20.4 \pm 2.1$ & $17.0-23.7$ & 10 \\
\hline & Smallest $(\mu \mathrm{m})$ & 18 & $18.7 \pm 1.4$ & $17.0-21.1$ & 7 \\
\hline
\end{tabular}

${ }^{a}$ Pore canals on surface of zona radiata at vegetative pole.

${ }^{b}$ External micropyle opening.

areas in the water with low light such as under rocks or at the river edge. The eggs then become slightly adhered to substrates, such as roots, are covered by leaves and abandoned by their parents (Viveiros et al., 2012).

The biopsied oocytes from B. nattereri exhibited a histochemical pattern, with acidic polysaccharides found in the cortical alveoli; this pattern is similar to that of species of the families Characidae (Brycon lundii, Brycon orbignyanus, Salminus maxillosus, Salminus brasiliensis and Salminus hilarii; Bazzoli \& Godinho, 1994) and Erythrinidae (Hoplerythrinus unitaeniatus, Hoplias lacerdae and Hoplias malabaricus; Gomes et al., 2007). However, the oocytes of female Characiformes from the families Anostomidae and Curimatidae have been found to contain only neutral polysaccharides in the cortical alveoli (Bazzoli \& Godinho, 1994). In addition to species-specific variations in carbohydrate content in the cortical alveoli, variations have also been found in the composition of these alveoli during oocyte maturation (Ohta et al., 1990). Acidic polysaccharides in the cortical alveoli are released into the perivitelline space during the cortical reaction, when these substances interact with the zona radiata and may contribute to blocking polyspermy (Tyler \& Sumpter, 1996).

The stripped oocytes from B. nattereri were spherical and had a diameter with a mode at $2.375 \mathrm{~mm}$. The oocyte surface exhibited a single, funnel-like shaped micropyle and pore canals, similar to that found for other species of Characiformes (Rizzo et al., 2002; Ganeco \& Nakaghi, 2003; Ganeco et al., 2009; Alexandre et al., 2010; Isaú et al., 2013). The micropyle is a concave region that is located on the oocyte surface and is composed of a continuous vestibule with an internal canal that narrows progressively toward the plasma membrane of the egg (Ganeco \& Nakaghi, 2003) to allow the entrance of a single spermatozoon during fertilization and thus blocking polyspermy.

In conclusion, Brycon nattereri females display group-synchronous-type oocyte development, and exhibit characteristics that differ from other species of the genus such as fecundity, egg size and egg adhesiveness. The findings of the current study provide essential information for a better understand- ing of the reproductive biology of $B$. nattereri and the establishment of conservation measures for this threatened species.

\section{Acknowledgements}

The authors wish to thank G.A. Azarias and J.M. Silva (CEMIG Itutinga Unit, MG) for assistance during oocyte collection; the Brazilian fostering agency FAPEMIG (project CVZ-1609/06) for financial support; and Dr E. Alves for allowing the use of the Electron Microscopy and Ultrastructural Analysis Laboratory of UFLA.

\section{References}

Alexandre, J.S., Ninhaus-Silveira, A., Veríssimo-Silveira, R., Buzollo, H., Senhorini, J.A. \& Chaguri, M.P. (2010). Structural analysis of the embryonic development in Brycon cephalus (Günther, 1869). Zygote 18, 173-83.

Andrade-Talmelli, E.F., Kavamoto, E.T., Narahara, M.Y. \& Fenerich-Verani, N. (2002). Reprodução Induzida da piabanha, Brycon insignis (Steindachner, 1876) (Characiformes, Bryconinae), mantida em confinamento. Rev. Bras. Zootec. 31, 803-11.

Bazzoli, N. \& Godinho, H.P. (1994). Cortical alveoli in oocytes of freshwater neotropical teleost fish. Boll. Zool. 61, 30108.

Ganeco, L.N. \& Nakaghi, L.S.O. (2003). Morfologia da superfície dos ovócitos e caracterização da micrópila de piracanjuba, Brycon orbignyanus, sob microscopia eletrônica de varredura. Acta Sci. 25, 227-31.

Ganeco, L.N., Franceschini-Vicentini, I.B. \& Nakaghi, L.S.O. (2009). Structural analysis of fertilization in the fish Brycon orbignyanus. Zygote 17, 93-9.

Gomes, B.V.C., Scarpelli, R.S., Arantes, F.P., Sato, Y., Bazzoli, N. \& Rizzo, E. (2007). Comparative oocyte morphology and early development in three species of trahiras from the São Francisco River basin, Brazil. J. Fish Biol. 70, 141229.

Gomiero, L.M. \& Braga, F.M.S. (2007). Reproduction of pirapitinga do sul (Brycon opalinus, Cuvier, 1819) in the Parque Estadual da Serra do Mar-Núcleo Santa Virgínia, São Paulo, Brazil. Braz. J. Biol. 67, 541-49.

Grier, H. \& Neidig, C. (2011). Gonads and gametes of fishes. In Cryopreservation in Aquatic Species, 2nd edn (eds. T.R. Tiersch \& C.C. Green), pp. 19-32. Baton Rouge, LA, USA: The World Aquaculture Society. 
Isaú, Z.A., Rizzo, E., Amaral, T.B., Mourad, N.M.N. \& Viveiros, A.T.M. (2013). Structural analysis of oocytes, post-fertilization events and embryonic development of the Brazilian endangered teleost Brycon insignis (Characiformes). Zygote 21, 85-94.

Kramer, D.L. (1978). Terrestrial group spawning of Brycon petrosus in Panamá. Copeia 1978, 536-37.

Lima, F.C.T., Albrecht, M.P., Pavanelli, C.S. \& Vono, V. (2007). Threatened fishes of the world: Brycon nattereri Günther, 1864 (Characidae). Environ. Biol. Fishes 1, 1-2.

Narahara, M.Y., Andrade-Talmelli, E.F., Kavamoto, E.T. \& Godinho, H.M. (2002). Reprodução induzida da pirapitinga-do-sul, Brycon opalinus (Curvier, 1819), mantida em condições de confinamento. R. Bras. Zootec. 31, 1070-75. [in Portugese]

Ohta, T., Iwamatsu, T., Tanaka, M. \& Yashimoto, Y. (1990). Cortical alveolus breakdown in the eggs of the freshwater teleost Rhodeus ocellatus ocellatus. Anat. Rec. 227, 486-96.

Oliveira, A.V., Viveiros, A.T.M., Maria, A.N., Freitas, R.T.F. \& Izaú, Z.A. (2007). Sucesso do resfriamento e congelamento de sêmen de pirapitinga Brycon nattereri. Arq. Bras. Med. Vet. Zootec. 59, 1509-15. [in Portugese]

Pearse, A.G.E. (1985). Histochemistry: Theoretical and Applied. London: Churchill Livingstone.

Riehl, R. \& Patzner, R.A. (1998). The modes of egg attachment in teleost fishes. Ital. J. Zool. 65, 415-20.

Rizzo, E. \& Bazzoli, N. (1991). The zona pellucida of the Brazilian white piranha, Serrasalmus brandtii Reinhardt, 1874 (Pisces, Characidae): a cytological and cytochemical study. Funct. Dev. Morphol. 1, 21-4.

Rizzo, E. \& Godinho, H.P. (2003). Superfície de ovos de peixes Characiformes e Siluriformes. In Águas, Peixes e Pescadores do São Francisco das Minas Gerais (eds. H.P. Godinho \& A. L. Godinho), pp. 115-132. Belo Horizonte, MG, Brazil: PUC Minas. [in Portugese]
Rizzo, E., Sato, Y., Barreto, B.P. \& Godinho, H.P. (2002). Adhesiveness and surface patterns of eggs in neotropical freshwater teleosts. J. Fish Biol. 61, 615-32.

Rosa, R.S. \& Lima, F.C.T. (2008). Os peixes brasileiros ameaçados de extinção. In Livro Vermelho da Fauna Brasileira Ameaçada de Extinção, 2nd vol. (eds. A.B.M. Machado, G.M. Drummond \& A.P. Paglia), pp. 8285. Belo Horizonte, MG, Brazil: Fundação Biodiversitas. [in Portugese]

Sato, Y., Fenerich-Verani, N. \& Godinho, H.P. (2003). Reprodução induzida de peixes da bacia do São Francisco. In Águas, Peixes e Pescadores do São Francisco das Minas Gerais (eds. H.P. Godinho \& A.L. Godinho), pp. 275-89. Belo Horizonte, MG, Brazil: PUC Minas. [in Portugese]

Tyler, C.R. \& Sumpter, J.P. (1996). Oocyte growth and development in teleosts. Rev. Fish Biol. Fish. 6, 287-318.

Van Zutphen, L.F., Baumans, V. \& Beynen, A.C. (2001). Principles of Laboratory Animal Science: A Contribution to the Humane Use and Care of Animals and to the Quality of Experimental Results. Revised edition. Amsterdam: Elsevier.

Viveiros, A.T.M., Maria, A.N., Amaral, T.B., Orfão, L.H., Isaú, Z.A. \& Verissimo-Silveira, R. (2012). Spermatozoon ultrastructure and sperm cryopreservation of the Brazilian dry season spawner fish pirapitinga, Brycon nattereri. Aquac. Res. 43, 546-55.

Weber, A.A., Arantes, F.P., Sato, Y., Rizzo, E. \& Bazzoli, N. (2012). Oocyte adhesiveness and embryonic development of Astyanax bimaculatus (Linnaeus, 1758) (Pisces: Characidae). Zygote 21,198-202.

West, G. (1990). Methods of assessing ovarian development in fishes: a review. Aust. J. Mar. Freshwater Res. 41, 199-222.

Zaniboni-Filho, E., Reynalte-Tataje, D. \& Weingartner, M. (2006). Potencialidad del género Brycon en la piscicultura brasileña. Rev. Colomb. Cienc. Pecu. 19, 233-40. [in Spanish] 